\title{
Risk Analysis with Decision Tree Method on the Use of Electronic Flight Bags: A Case Study on Pilots
}

\author{
Haşim Kafalı ${ }^{*}$, Savaş Selahattin Ateş ${ }^{2}$ \\ $1^{*}$ Muğla Sttkı Koçman University, Dalaman School of Civil Aviation, Muğla, Turkey, (ORCID: 0000-0002-7740-202X), hasimkafali@mu.edu.tr \\ ${ }^{2}$ Eskişehir Technical University, Faculty of Aeronautics and Astronautics, Eskisehir, Turkey, (ORCID: 0000-0003-2462-0039), ssates@eskisehir.edu.tr
}

(First received 16 April 2021 and in final form 24 July 2021)

(DOI: 10.31590/ejosat.917743)

ATIF/REFERENCE: Kafal1, H., \& Ateş, S.S., (2021). Risk Analysis with Decision Tree Method on the Use of Electronic Flight Bags: A Case Study on Pilots. European Journal of Science and Technology, (25), 562-570.

\begin{abstract}
The need to reach far afield, which is a part of human life, is provided by different modes of transportation according to the available facilities and needs. Air transport has an important place in our lives with its speed and some features superior to other modes of transport. Air transportation stands out the risk of flight in the transportation modes. Air transportation keeps the important pace with the developing technology every day. Electronic flight bags, which have been used by airline transportation in recent years and are becoming increasingly widespread, are preferred due to their economy and efficiency. In this study, one of the safest modes of transport Risk analysis was performed using the decision tree method on the use of electronic flight bags for airline transportation. With this analysis, it is aimed to reduce risks and maximize airway safety. For the use of the decision tree method was inspired by the SHELL model and the decision tree method was applied on the interaction of electronic flight bags with the environment, hardware, software and live ware. According to the survey analysis results applied to the pilots of the two airline companies, the lowlevel risk was determined as a result of the interaction of electronic flight bags with electronic flight bags with hardware, while a high risk in interaction with software and humans and a very high risk in interaction with the environment was detected.
\end{abstract}

Keywords: Electronic Flight Bags, Hazard, Risk Analysis, Decision Tree, Aviation.

\section{Elektronik Uçuş Çantalarının Kullanımının Karar Agacı Yöntemiyle Risk Analizi: Pilotlar Üzerine Örnek Çalışma}

$\ddot{\mathbf{O z}}$

İnsan yaşamının bir parçası olan bir yerden bir yere ulaşma ihtiyacı elde bulunan imkân ve ihtiyaçlara göre farklı ulaşım modlarıyla sağlanmaktadır. Havayolu taşımacılığı da hız ve diğer ulaşım modlarına göre üstün birtakım özellikleriyle hayatımızda önemli bir yere sahiptir. Havayolu taşımacılığı emniyetli bir taşımacılık olması ile öne çıkmaktadır. Her geçen gün gelişen teknolojiye havayolu taşımacılığ 1 da ayak uydurmaktadır. Havayolu taşımacılı̆̆ 1 tarafindan son yıllarda kullanılmaya başlanan ve giderek yaygınlaşan elektronik uçuş çantaları ekonomikliği ve verimliliği sayesinde tercih sebebi olmaktadır. Bu çalışmada en emniyetli ulaşım modlarından olan havayolu taşımacılığı için elektronik uçuş çantaları kullanımının üzerine karar ağacı yöntemi ile risk analizi yapılmıştır. Yapplan bu analizle riskleri azaltarak havayolu emniyetini maksimize hale getirmek amaçlanmıştır. Karar ağacı yöntemi kullanımı için tehlike belirlemesinde SHELL modelinden esinlenilmiş ve elektronik uçuş çantalarının çevre, donanım, yazılım ve insanla olan etkileşimi üstüne karar ağacı yöntemi uygulanmıştır. İki havayolu şirketinin pilotlarına uygulanan anket analiz sonuçlarına göre, elektronik uçuş çantalarının elektronik uçuş çantalarının donanımla etkileşimi sonucu düşük seviyede risk tespit edilmişken, yazılım ve insanla olan etkileşiminde yüksek risk ve çevre ile etkileşiminde çok yüksek risk tespit edilmiştir.

Anahtar Kelimeler: Elektronik Uçuş Çantaları, Tehlike, Risk Analizi, Karar Ağacı, Havacılık.

\footnotetext{
*Corresponding Author: hasimkafali@mu.edu.tr
} 


\section{Introduction}

Transportation has been one of the most important elements of our lives in terms of making human life easier from the past to the present. From the invention of the wheel to the present, it has renewed itself in continuous development and change, and has taken its place today equipped with the latest technologies (Khan et al., 2018).

In the scope of the development and change processes of the 21 st century, it is seen that human beings' search for the sky and space covers an important area among the technological elements. The curiosity of the sky, which has been continuing since the day humanity existed, has reached the depths of space with the developing technology (Puranik et al., 2020).

Many modes of transport make our life easier, however the most advantageous of these in terms of speed and time benefits is undoubtedly air transportation. In its simplest definition of air transportation is the displacement of people, cargo (cargo), and mail from the air with an aircraft to provide space and time benefits. This relocation will not provide any benefit unless it is done safely and will cause many damages to the company and the environment. They apply a safety management system to protect this benefit and prevent possible damages. It is to identify the underlying hazards of the safety management system and to reduce the risks to low or acceptable levels (Carbo and Graham, 2020; Delgado et al., 2020).

Airline transportation is also closely following and applying the developing technology with every passing day. Electronic flight bags, which have been increasingly used in airline transportation in recent years, are a product of developing technology. It is the obligation of airline transportation companies to determine the dangers and risks against the flight safety of these electronic flight bags and to take corrective preventive action against these dangers and risks. Otherwise, it is possible for the company to be damaged by causing an accident or incident, as well as causing great damage to the environment. There are different methods for risk analysis of hazards. One of these methods is the decision tree method. With the decision tree method, it is possible to determine the severity of the incident that may occur as a result of the identified dangers. In this study, a risk analysis has been made using the decision tree method on the use of electronic flight bags.

\section{Electronic Flight Bag Definition, Advantages for Airlines}

Electronic Flight Bag (EFB) is defined as a system that keeps the information that pilots need during the flight and stored on paper electronically, can be integrated with the avionic systems on the aircraft, and allows the creation and management of documents created during the flight in electronic environment.

In general terms, EFB includes the printed reference documents that pilots carry and use in flights and which can be found in the cockpit fixed inside the aircraft, including the aircraft operating manual, cabin crew operating manual and navigational charts that pilots can use before and during the flight, also called "Flight Bag". They are computer platform applications that will completely replace them over time. In addition, EFB can also incorporate purposeful sub-applications that allow automatic calculations such as pre-flight performance analysis, which are normally carried out manually and are very important for flight. EFB takes its name from a bag of documents weighing 20 $25 \mathrm{~kg}$ that pilots carry into the cockpit before each flight. Electronic Flight Bag is an application that digitally replaces these documents. EFB applications are used on tablet computers weighing between 0.5 and $2.2 \mathrm{~kg}$. Thus, the functions of a traditional flight bag can be performed with a tablet fixed to the plane or carried with the pilot. With the cheaper mobile tablet hardware in the last few years, EFB systems have become more cost effective and take place in the world of civil aviation.

The use of EFB has many advantages for airlines. As the transaction sizes of EFBs , the types of applications used, and the content management and distribution systems available in EFB change, the unique benefits of EFBs also change and are updated. In general, the benefits of using EFB are as follows; The reduction in costs and increased efficiency due to the reduction or elimination of operations on printed papers, weight savings and health problems caused by the weight of the bag, reduction of the pilot's workload, easy access to the necessary information when requested, pilots situational awareness, automatic take-off and landing calculations to reduce fuel and maintenance costs (Köse, Ayanoğlu, Erel, \& Gündüz, 2016).

\subsection{Classification and Characteristics of EFB Systems}

According to the electronic flight bag equipment features; It is examined in three groups as Class 1, Class 2 and Class 3 (ICAO, 2014).

Class 1 EFB systems;

- $\quad$ They are Commercial- Off - The-Shelf(COTS) -based computer systems that are generally used for flight operations .

- Portable,

- Connected to aircraft power with a certified power source,

- Considered as a controlled PED ,

- Not connected to the mounting device on the plane,

- No aircraft data

connection except under certain conditions,

- These are systems that do not require approval for airworthiness (EASA, 2014).

Class 2 EFB systems;

- They are Commercial- Off - The-Shelf(COTS) -based computer systems that are generally used for flight operations .

- Portable,

- Connected to aircraft power with a certified power source,

- Connected to the aircraft mounting device during normal flight operations,

- Considered as a controlled PED,

- Avionic connection is possible,

- These are systems that require airworthiness approval (EASA, 2014). 
Class 3 EFB systems;

- $\quad$ Aircraft airworthiness approval required equipment as i nstalled.

- The intended function and safety interface must be applicable to avionic data sources and other software applications.

- Failures of the interface between EFB and avionic data sources should be evaluated under normal and fault conditions.

- The application's own approval should also be considered when evaluating the reliability and suitability of the software application.

- A limited assessment of human factors should be made.

- EFB hardware resources such as display, keyboard, signal indicators and control buttons should be evaluated (EASA, 2014).

Type A and B software applications do not require airworthiness approval, but must be approved during the operational approval process.

Type A software applications contain data that has already been created and is currently presented in paper format (EASA, 2014). They can belong to any class of equipment, they require operational approval, they do not require airworthiness approval. Type B software applications include dynamic and interactive applications where you can make changes in data and presentations (EASA, 2014). They can be in any class of equipment, they do not require airworthiness approval.

\subsection{Documentation}

There are documents and manuels including flight manuals, developer guides for EFB software applications and guides for EFB system suppliers.

For installed EFB systems and certified loaded resources, the AFM section or annex should include the following parts (EASA, 2014):

- A statement regarding the suitability of EFB equipment for flight

- Identification of installed hardware

- Appropriate changes and reinforcements for any restrictions

This guide should mainly address the following issues;

- An architectural description for EFB installed components,

- For the Enhancement Assurance Level of EFB components and any assumptions, limitations, or mitigating factors

- Necessary information to ensure the development of an accurate, reliable, safe, testable and sustainable software application compatible with the avionics interface and the human machine interface,

Integration procedures between approved software applications and new software applications should be available at least the flight operators authorized institutions and organizations (EASA, 2014).
The guide is designed for use by the EFB system provider and addresses the following guidelines mainly.

- Descriptions of installed EFB resources and their limitations,

$$
\begin{aligned}
& \circ \quad \text { The intended functions and usage limitations, } \\
& \circ \quad \text { Features of mounting devices, control and sign } \\
& \text { panels, display units, }
\end{aligned}
$$

- Characteristics and limitations of safety and security aspects

$\begin{array}{cl}\circ & \text { Power source } \\ \circ & \text { Lithium Battery } \\ \circ & \text { Data link }\end{array}$

The guide should be at least the flight operators in authorized institutions and organizations (ICAO, 2014).

\subsection{EFB's Operational Evaluation and Approval Process} below:

The process specified for EFB usage approval is processed

\subsubsection{Risk assessment}

The purpose of this process is to show that the software application provides the same level of integrity and usability. This assessment will be operator specific and is expected to address mainly the following awe.

- Minimizing undetected erroneous application output

- To detect faulty outputs from the software application, in cases where it cannot be detected;

$$
\begin{array}{ll}
\circ & \text { Crew tracking } \\
\circ & \text { Fault scenarios }
\end{array}
$$

- Analyzing the operational results of failure scenarios

- Mitigating measures for undesirable situations

- Quality improvement process

$$
\begin{aligned}
& -\quad \text { Reliability of basic data used in practice } \\
& \circ \quad \text { Application verification and approval controls }
\end{aligned}
$$

(EASA, 2014).

\subsubsection{Role of the System Provider}

System suppliers are obliged to meet the usage requirements of software and hardware of EFB users. Companies are starting to use EFB application; They request compliance reports from the system supplier to obtain the approval of the relevant national authority (DGCA). In order to obtain the approval of the relevant authority, companies have the right to request the documents regarding the use and the training and certification of the relevant employees in the company, as well as the suitability for use report. It is also under the obligation of system suppliers to monitor the innovation and update processes that the operators want to make in EFB software and hardware in a way that does not disrupt the integrity of EFB systems (ICAO, 2014). 


\subsubsection{Evaluation of Human / Machine Interface Application / Human Factors}

When the airline operator uses the EFB system, it is necessary to assess the system's human machine interface compatibility and its use in cockpit resource management. In this evaluation, the entire system should be reviewed and should include the following points;

- Human / machine interface

- Text readability

- Approach / departure and navigation graphic screens

- Application sensitivity

- Closed screen text and content

- Active zones

- Managing when multiple applications and documents are open

- Messages and the use of color

- System error messages

- Data entry scanning and error messages (EASA, 2014).

\subsubsection{Flight Crew Working Procedures}

- Procedures for Combining Use of Other Flight Cockpit Equipment and EFB Systems: Procedures should be determined so that the flight crew know the intended use of EFB systems and other flight equipment. Procedures should explain what the flight crew must do if the information provided by EFB systems is inconsistent with the information provided by other flight equipment. If the EFB system and the information of other existing systems are consistent, it should be clearly determined which source will be used primarily, which source will be used to back up the information produced, and in which cases the data in the backup source will be used (EASA, 2014).

- EFB Software / Database Revisions in Flight Crew Awareness: Flight crews should be capable of easily verifying EFB database version activity. Howe ver, flight crews are not required to confirm the renewal dates of other databases that do not adversely affect flight operations, such as daily maintenance lists, airport codes. The procedures should specify whether software applications or databases uploaded to the EFB system are up to date should be addressed (EASA, 2014).

- Workload Reduction / Control Procedures: Procedures should be established to reduce or control the workload by using the EFB system. Operators should follow these procedures so that the flight crew does not engage in both the aircraft and EFB systems during flight or surface movement. Workload; It should be shared among the flight crew to ensure ease of use and to keep track of other flight equipment and flight. These procedures must be strictly followed for each flight and timely informed which flight crew is not competent to use EFB systems (EASA, 2014).

- Defining Flight Crew Responsibilities for Performance Calculations: The procedures should define the new roles the flight crew and dispatch office may have in the use of performance calculations supported by EFB systems (EASA, 2014).

\subsubsection{Quality Assurance}

The operator should make a written inventory of the procedures required for the quality control of the EFB system. In addition, the general manager of the EFB system should be determined. Who will be authorized to approve and enable innovations in software and hardware in the EFB system should be defined in detail. Procedures should be determined with the assurance of EFB system integrity in case of EFB system maintenance and malfunction / failure. Maintenance procedures need to include up-to-date information uploading and how this will then be communicated to all users and relevant authorities. There should be backup procedures to be applied in case of system malfunctions and a reporting system to prevent the use of erroneous information by flight crews.

Intervention of unauthorized persons of EFB systems should be prevented. In order to prevent unauthorized intervention, a password should be used and the physical security of the hardware should be ensured. Precautions should also include checking laptop software installations to prevent unauthorized data use (EASA, 2014).

\subsubsection{Compliance Monitoring}

Airline operators can monitor EFB systems compliance monitoring ORO.GEN .200. should do according to requirements. The aim is to provide confidence that EFB activities and management decisions are made in accordance with all applicable standards, requirements and operational procedures (ICAO, 2014).

\subsubsection{EFB Administrator's Role}

The role of the EFB manager is an important factor in the functioning of the EFB system. The system administrator must receive the necessary training for the position, and must have sufficient knowledge of system hardware and operating systems. Another task of the EFB Manager is to ensure that the procedures are followed by all company personnel and to be responsible for audits on this issue. EFB managers mainly; It is responsible for all installed applications and the support of these installed applications to EFB users, to check possible security problems related to installed applications, to manage the configuration of software and hardware and to ensure the integrity of the data packets used in installed applications (ICAO, 2014; EASA, 2014).

\subsubsection{Flight Crew Training}

Special training must be given to the flight crew prior to approval for use. This training should mainly include the following points;

- System architecture overview

- System pre-flight checks

- System constraints

- Special training on the conditions of use of a particular application / under what conditions it cannot be used

- Restrictions on the use of the system in cases where all or a part of the system is out of use

- Cross-check procedures of data entry 
- Flight stages when EFB system is in use / not in use

- CRM and human factors considerations in using EFB

- Additional training on new applications or changes in hardware configuration (EASA, 2014).

\subsubsection{System Security}

The procedures required to ensure system security should be simple, transparent and easy to understand for ease of follow-up and inspection. Typical safety and security defense mainly includes the following aspects;

- Individual system firewalls

- Data encryption and authentication

- Virus scans

- VPN

- Creating a 'White List' for allowed internet domains

- Granting access right on the basis of need

- Forensic tools and procedures

- Virtualization (ICAO, 2014).

\subsubsection{Operational Evaluation Test}

The operator must conduct an operational assessment test to verify that there is no problem with the elements described above and his satisfaction before the final operational compliance report is issued.

The operator must notify the competent authorities that S/he wishes to conduct an operational evaluation test within a schedule. This planning should mainly include the following issues;

- Start date of an operational assessment test

- Time

- Planes to be covered

- Classes of EFB software and hardware

- Times when there is no back up of documents

$$
\begin{array}{ll}
\circ & \text { EFB detailed risk assessment } \\
\circ & \text { LOFT session program simulator }
\end{array}
$$

- Planned flights for monitoring by authorities (ICAO, 2014).

In cases where the files are initially preserved, the operational evaluation test is carried out in two stages. In the first stage, it is examined whether the filing is parallel to the equivalent filing format in order to prove the accuracy and reliability of the system. This is normally a six-month process, but it can change at the discretion of the national authority. Evaluation; It should also include the control of the applied procedures and the accuracy of the computed data entered from the computers. Reports obtained after the completion of the first phase must be sent to the competent national authority to approve the use of EFB systems instead of the filing format. In the second stage, the files should be kept as a precaution in case EFB systems are out of use or in case of any malfunction. When satisfied with the file backup procedures, the national authority can approve that files are not carried on board. (ICAO, 2014; EASA, 2014).
The operational evaluation test to evaluate whether the operators can start operations without backing up files should include the following elements;

- Detailed examination of operational risk analysis

- Authority's observations on the first line flights

- EFB 's normal, LOFT session aimed to verify the availability of an abnormal and emergency operating conditions, such as simulation of (EASA, 2014).

\subsubsection{Operational Compliance Summary}

All activities carried out by the operator of the EFB system operational supports a harmony in nature, outlining that it is operational should create a compliance report. This report mainly includes the following issues;

- Identifying EFB hardware / platform

- Description of software applications, including approval

- Risk analysis summaries for the applications used

- Human factors assessment for the entire EFB system ○ Pilot workload in single pilot / multi-crew aircraft

- Size, resolution, symbol and text readability

Evaluation of navigation graphic screens

- Education

- $\quad$ EFB manager qualification (EASA, 2014).

\section{Material and Method}

A decision tree is a decision support tool that uses a tree-like model to show decisions and their likely outcomes. It is a way to show an algorithm. Decision trees are used in research applications, especially in decision analysis, to determine the path to follow to reach a result (Moctezuma et al, 2012; Dozik, 2019).

Decision trees are used in decision analysis, statistics, data mining and artificial learning. In decision analysis, the decision tree can visually describe the decisions and the decision-making process, but in data mining, decision trees are used to describe the data; they do not define decisions (Quinlan, 1990). Decision analysis can be defined as the process of presenting the existing information, values and logic that can be applied to the decisionmaking process and to the most accurate of at least two options. While doing this, models are created by assigning probability and utility values for every situation that may be encountered. Thus, each situation is expressed by numbers, making it easier to compare the situations (Rios Insua et al, 2018).

Decision trees can be considered to be flowchart-like structures. It can be used to organize and showcase decisions. It has the advantages of using and understanding visually and intuitively. The decision tree has the following elements (Moctezuma et al, 2012; Moshkov, 2021;):

a) Inner node: This node evaluates or tests a feature.

b) Branch: Shows the result of the evaluation in the inner node.

c) End node or result node: Indicates the decision to be addressed. 
The decision-making process starts on the basis of the tree model, a specific feature is evaluated in the inner node, the next branch is selected according to the result of the evaluation. The selected branch takes you to another evaluation node, and this process continues until the last node is reached. Values of different traits evaluated in this way lead to different decisions (Moctezuma et al, 2012; Uysal \& Güyer, 2014).

Decision trees have different usages. They are used in data analysis and data mining to classify data and their names that are also referred to as classification trees. The purpose of this usage is to obtain information about all the data rather than making a decision on a subject (Uysal \& Güyer, 2014).

Another usage of decision trees is risk analysis. For risk analysis, it can be decided to measure the severity of the danger by evaluating the current situation. According to the branches selected as a result of the risk analysis internal nodes, the end node may have very high, high, medium and low level risks. In this research, the decision tree method was used for the risk analysis of electronic flight bags.

\section{Results and Discussion}

It is the selection of which areas to be applied as the first step of the decision tree. The selection of these areas was made by using the SHELL model. EFB-vision, EFB-software, EFB-human and EFB-hardware interaction were chosen instead of humanhardware, human-software, human-human and humanenvironment interaction in SHELL model.

Result nodes were determined by taking expert opinions while evaluating risks in order to achieve correct results. In some result nodes, the risks are considered very high, in some result nodes high, and in some result nodes medium or low level. This decision tree risk studies discussed are shared below (Figure 1).

Figure 1. EFB-Hardware Decision Tree

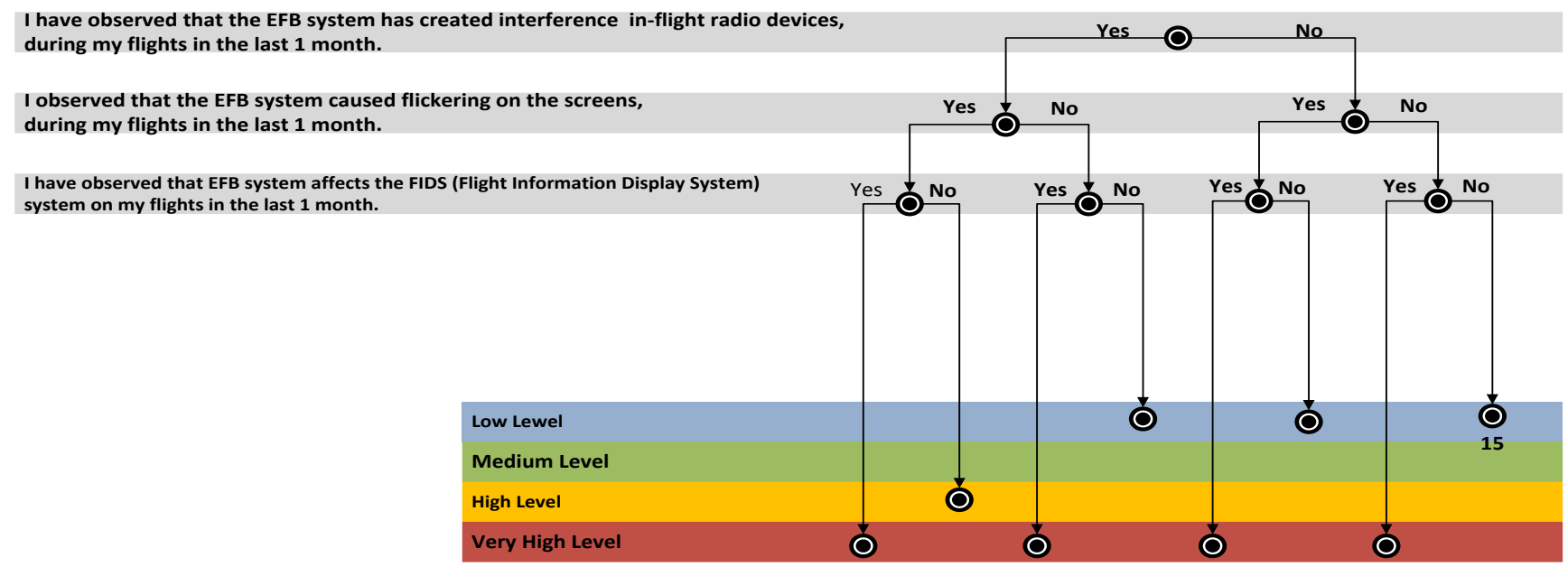

Participants did not answer yes in the questionnaire conducted to 3 questions determined within the scope of EFB and hardware interaction. This situation can be interpreted as there is no danger in EFB and hardware interaction (Figure 2).

Figure 2 . EFB- Human Decision Tree

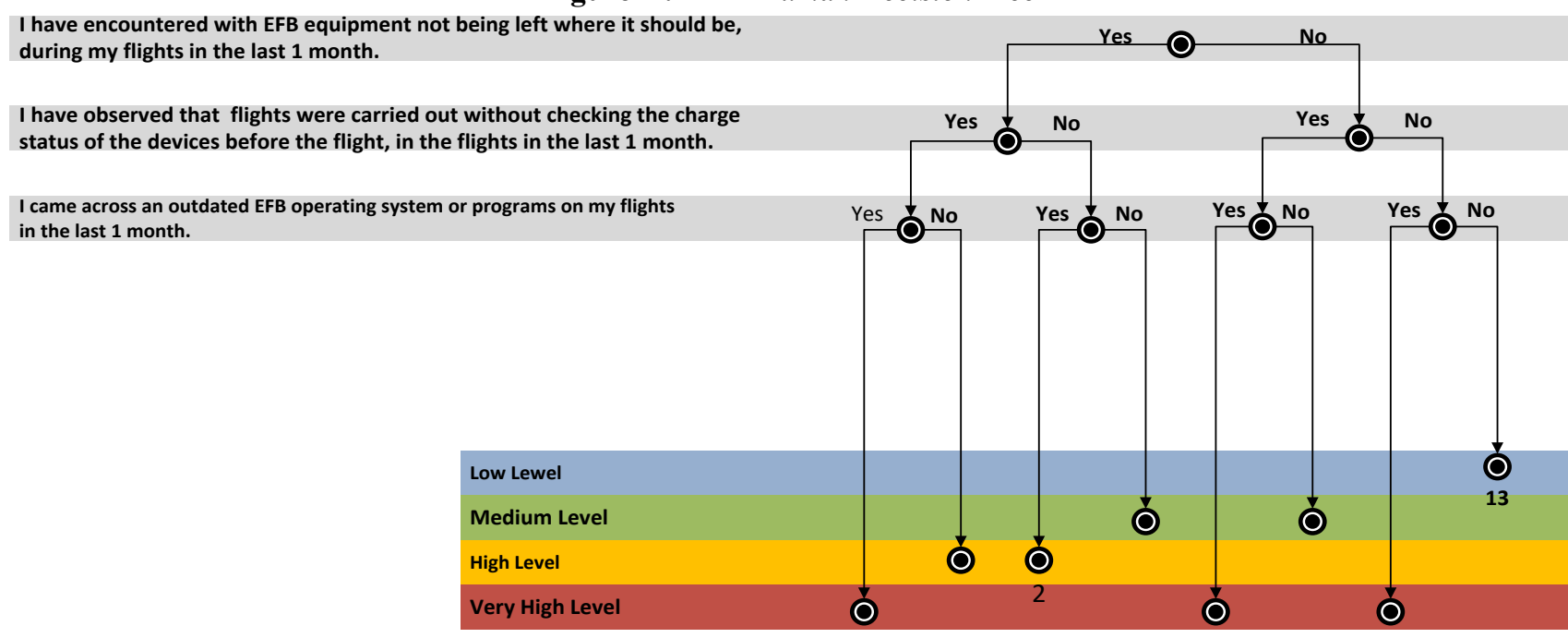

While 2 participants answered yes to the first and third questions in the questions determined within the scope of EFB and human interaction, all of the participants answered no to the second question. It is seen that this situation involves a high level of risk in decision tree analysis (Figure 3). 
Figure 3.EFB-Environment Decision Tree

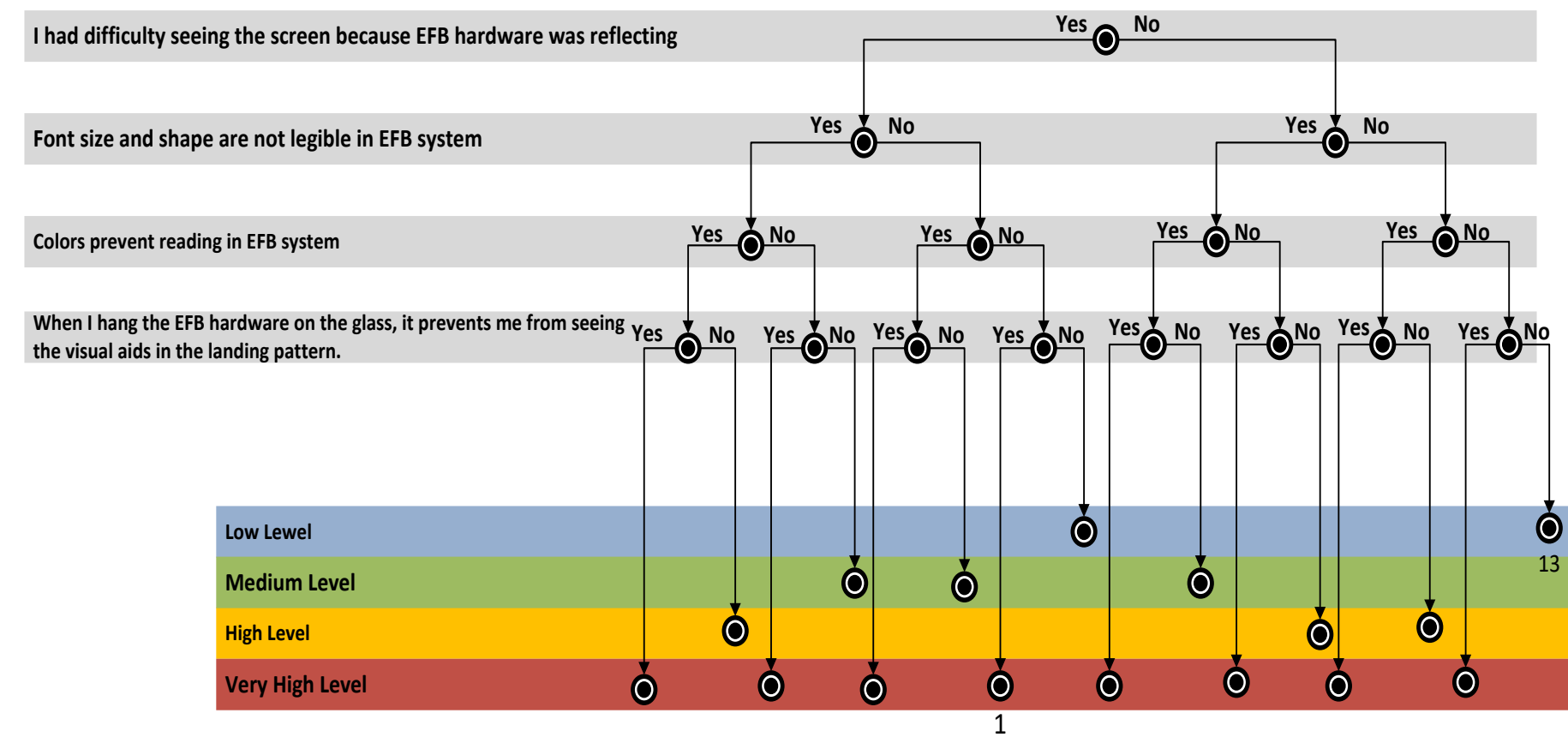

To the questionnaire questions determined within the scope of EFB and environment interaction, 2 participants answered yes to the first question, 1 participant to the second question, 1 participant to the third question, and 2 participants to the fourth question. It is seen that this situation falls into the very high risk area in the decision tree analysis (Figure 4).

Figure 4 . EFB-Software Decision Tree

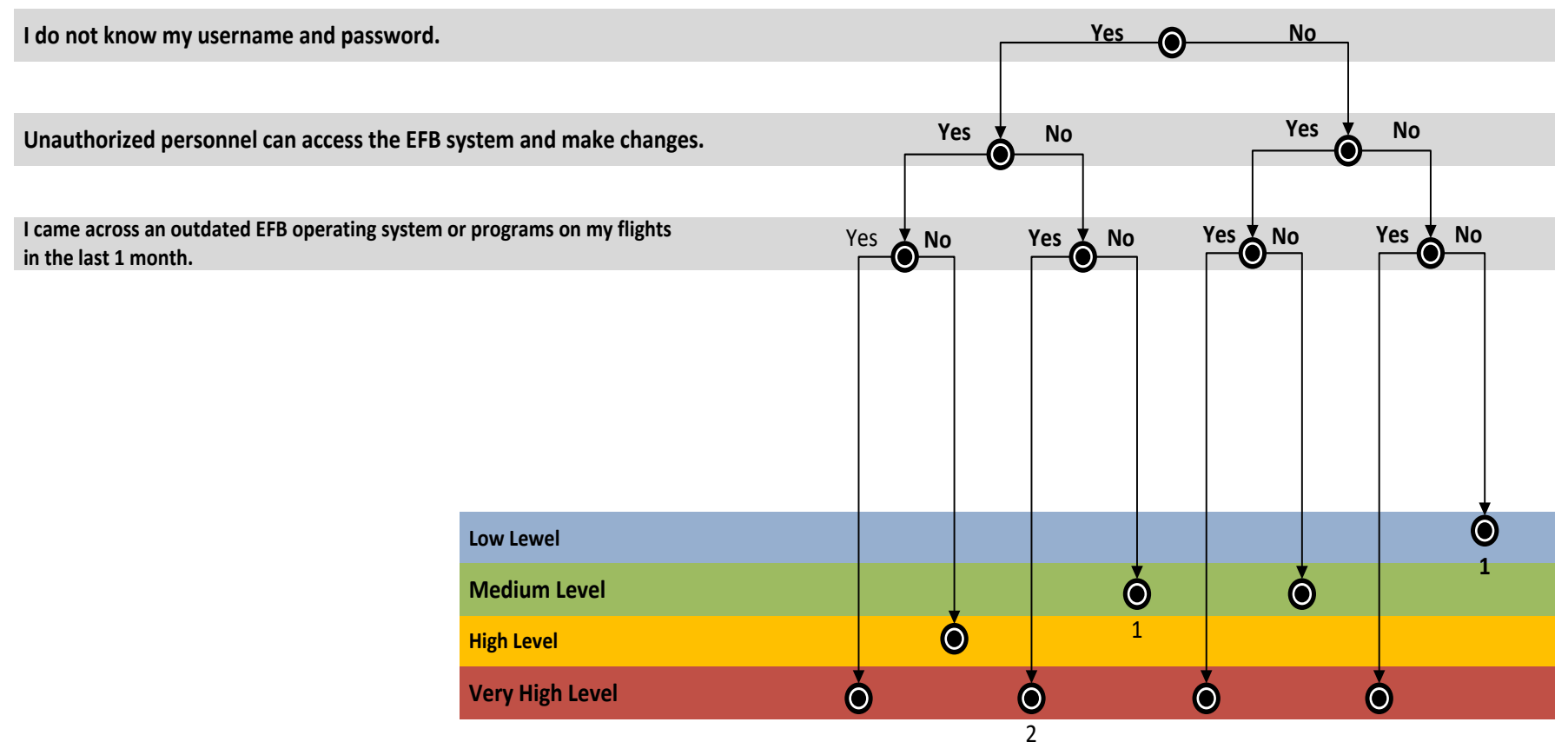

To the questionnaire questions determined within EFB and software interaction, 3 participants answered yes to the first question and 2 participants to the third question, while all

The distribution rates of the answers for the EFB scale are given in Table 1 . The distribution by size can be seen, with the total number of participants being 15 pilots. The answer "Yes", participants answered no to the second question. This situation is seen to be in a very high risk area in decision tree analysis.

which is considered as a risk factor, has been taken into account in the calculation of the rates. 
Table 1 . EFB-Software Decision Tree

\begin{tabular}{|c|c|}
\hline $\begin{array}{l}\text { EFB-Environment } \\
\text { Questions }\end{array}$ & Ratio of Yes Answer (\%) \\
\hline I had difficulty seeing the screen because EFB hardware was reflecting & 13.3 \\
\hline Font size and shape are not legible in EFB system & 6.7 \\
\hline Colors prevent reading in EFB system & 6.7 \\
\hline $\begin{array}{l}\text { When I hang the EFB hardware on the glass, it prevents me from seeing } \\
\text { the visual aids in the landing pattern. }\end{array}$ & 13.3 \\
\hline EFB-Hardware & \\
\hline Questions & Ratio of Yes Answer (\%) \\
\hline $\begin{array}{l}\text { I have observed that the EFB system has created interference in-flight radio devices, } \\
\text { during my flights in the last } 1 \text { month. } \\
\text { I observed that the EFB system caused flickering on the screens, } \\
\text { during my flights in the last } 1 \text { month. } \\
\text { I have observed that EFB system affects the FIDS (Flight Information Display System) } \\
\text { system on my flights in the last } 1 \text { month. }\end{array}$ & 0 \\
\hline EFB- Human & \\
\hline Questions & Ratio of Yes Answer (\%) \\
\hline $\begin{array}{l}\text { I have encountered with EFB equipment not being left where it should be, } \\
\text { during my flights in the last } 1 \text { month. }\end{array}$ & 13.3 \\
\hline $\begin{array}{l}\text { I have observed that flights were carried out without checking the charge } \\
\text { status of the devices before the flight, in the flights in the last } 1 \text { month. }\end{array}$ & 0 \\
\hline $\begin{array}{l}\text { I came across an outdated EFB operating system or programs on my flights } \\
\text { in the last } 1 \text { month. }\end{array}$ & 13.3 \\
\hline EFB-Software & \\
\hline Questions & Ratio of Yes Answer (\%) \\
\hline I do not know my username and password. & 20 \\
\hline Unauthorized personnel can access the EFB system and make changes. & 0 \\
\hline $\begin{array}{l}\text { I came across an outdated EFB operating system or programs on my flights } \\
\text { in the last } 1 \text { month. }\end{array}$ & 13.3 \\
\hline
\end{tabular}

\section{Conclusions and Recommendations}

At this stage, the questionnaire results were examined using the internal node points determined by the decision tree method around the SHELL model. The questions asked in the questionnaire made to 15 participants and the number of participants who answered yes to the questions are given in detail in the table below (Table 1.).

Inspired by the SHELL model, decision trees were determined in line with EFB-Environment, EFB-Hardware, EFBSoftware and EFB-Human interactions. In decision trees, the equivalents of inner nodes and inner nodes at the result nodes are decided. The determined internal nodes were asked to 15 participants by creating a questionnaire and the results of the risks in the use of EFB were provided as result nodes.

When the interaction of electronic flight bags and the environment was examined, 2 participants answered yes to the first question, 1 participant to the second question, and 2 participants to the third question. The answers given within the EFB and environment interaction show that it is in a very high risk category in the decision tree method.

When the electronic flight bags and hardware interaction were examined, it was observed that all of the participants answered no to the questions asked, and this shows that they are in the low-level risk category in the decision tree method.

When electronic flight bags and human interaction were examined, 2 participants answered yes to the first and third questions, while all participants answered no to the second question. This indicates that EFB and human interaction is in the high-level risk category.

When examined in electronic flight bags and software interaction, 3 participants answered yes to the first question and 2 participants to the third question, while all participants answered no to the second question. This shows that the software interaction is in the high risk category.

In general, in the results of the survey applied to 15 participants, the EFB system; It was concluded that there is a high risk in software and human interactions, a very high risk in environmental interaction and a low risk in hardware interaction.

Airline transport is a sector that uses high-tech products and closely follows technological development. Today's technological developments affect the airline transportation sector and cause the use of new technologies. One of these technologies is that old flight bags are replaced by portable or embedded electronic devices called electronic flight bags. The reasons why these electronic flight bags are preferred; There are reasons such as the decrease in fuel consumption due to the decrease in the load carried, the increase in labor productivity and savings in the membership fees paid for the road maps. For all these reasons, companies engaged in air transport prefer electronic flight bags and their use is increasing day by day.

In this study, a risk analysis has been made for the electronic flight bags used in the airline company. For this, the method called decision tree in the literature was used. Inspired by the SHELL model, the decision tree was created in the areas of the electronic 
flight bag's interactions with hardware, software, human and environment. Under these interaction areas, inner nodes were created and the result nodes were determined. Node endpoints are determined as low, medium, high and very high risk levels, indicating the risk of danger. Then, the questionnaire was created with the determined internal nodes and answered by the relevant pilots. In the questionnaire, it was aimed to reach the result nodes by asking the internal nodes as questions. As a result, with the answers given to the inner nodes, different risk levels at the result nodes have been reached. Thus, it is aimed to decide the risks in the use of electronic flight bags.

As a result of the study with the participation of 15 pilots, it was observed that there was a low level of risk in electronic flight bag hardware interaction, while it was observed that there was a high level of risk in its interaction with the environment and a high level of risk as a result of its interaction with human and software. It would be correct to examine these risky areas in detail and offer solutions and solutions.

3 participants answered yes to the question "I do not know my username and password" in electronic flight bag software interaction. Here, it can be said that reminding the pilots of their user names and passwords by the EFB administrator and giving the username and password if they are not given can be a solution. Two participants answered yes to another question in software interaction and human interaction, "I encountered an outdated EFB operating system or programs on my flights in the last month". Establishing a procedure for the operating system and programs and checking their updates frequently helps to reduce the risks that may arise.

In the electronic flight bag and human interaction, 2 participants answered yes to the question "I have encountered EFB equipment not being left where it should be on my flights in the last 1 month". At this point, as a solution, it will be determined exactly where the EFB devices will be left after the flight and stated in the EFB usage procedures will reduce the risk.

In the electronic flight bag and environment interaction, 1 participant each answered yes to the questions "fonts are not legible in subjects such as size and shape of fonts in EFB system" and "colors prevent reading in EFB system". In addition, 2 participants answered yes to the questions "When I hang the EFB hardware on the glass, it prevents me from seeing visual aids in the landing pattern" and "I had difficulty seeing the screen because the EFB equipment reflected ". Since it involves a very high risk of affecting the visual aids in the landing pattern, it is necessary to find a solution immediately. If it is considered appropriate for use on the knee, it will be an appropriate corrective action to be used to remove the apparatus used to hang on the glass and to use a pilot flight knee (kneeboard for pilot). Apart from this, it may be a solution to check the current status of the system and programs used to solve issues such as colors, font sizes and shapes, and use new different programs if necessary.

As a result, the use of electronic flight bags, which has many undeniable advantages, is increasingly common. In this research, risk analysis of electronic flight bags has been made using the decision tree method. As a result of the analysis, it has been realized that there were very high and high risk situations. Preventive and corrective actions to reduce these risks shall be taken. Thus, electronic flight bags will continue to be used more safely for the purpose of aviation safety, thus possible accidents, crimes and incidents will be prevented.

e-ISSN: 2148-2683

\section{References}

Carbo, J.M. and Graham, D.J., (2020). Quantifying The Impacts of Air Transportation on Economic Productivity: A QuasiExperimental Causal Analysis. Economics of Transportation, Vol 24, 1-13.

Delgado, L., Gurtner, G., Cook, A., Martin, J. and Cristobal, S., (2020). A multi-layer model for long-term KPI alignment forecasts for the airtransportation system. Journal of Air Transport Management, Vol 89, 1-12.

Dozik, S., (2019). Multi-criteria decision making methods: Application in the aviation industry. Journal of Air Transport Management, Vol 79, 1-22.

EASA. (2014). Airworthiness and operational consideration for Electronic Flight Bags.

ICAO. (2014). Annex II - AMC 20-25. Montreal, Canada.

Khan, H. U. R., Siddique, M., Zaman, K., Yousaf, S. U., Shoukry, A. M., Gani, S. G., Sasmoko, Khan, A. A. and Hishan, S.S. (2018). The impact of air transportation, railways transportation, and port containertraffic on energy demand, customs duty, and economic growth: Evidencefrom a panel of low-, middle-, and high -income countries. Journal of Air Transport Management, Vol 70, 18-35.

Köse, M., Ayanoğlu, E., Erel, E., \& Gündüz, C. (2016). Sivil Havacılıkta Mobil Teknolojilerin Kullanımı -Elektronik Uçuş Çantası.

Moctezuma, L. E., Lobov, A., \& Lastra, J. L. (2012). Decision making by using tree-like structures on industrial controllers. 2012 10th International Conference on ICT and Knowledge Engineering, (s. 77-83). Bangkok.

Moshkov, M., (2021). On the depth of decision trees over infinite 1-homogeneous binary information systems. Array, Vol 10, 14.

Puranik, T.G., Rodriguez, N., and Mavris, D.N., (2020). Towards Online Prediction of Safety-Critical Landing Metrics in Aviation Using Supervised Machine Learning. Transportation Research Part C, Vol 120, 1-18.

Quinlan, J. R. (1990). Decision trees and decision-making. IEEE Transactions on Systems, Man, and Cybernetics , 330-346.

Rios Insua, D., Alfaro, C., Gomez, J., Hernandez-Coronado, P. and Bernal, F., (2018). A framework for risk management decisions in aviation safety at state level. Reliability Engineering and System Safety, Vol 179, 74-82.

Uysal, M., \& Güyer, T. (2014). İstatistiksel Veri Analizine İlişkin Genişleyebilir Bir Karar Ağacı Tasarımı. Bilişim Teknolojileri Dergisi , 33-43. 